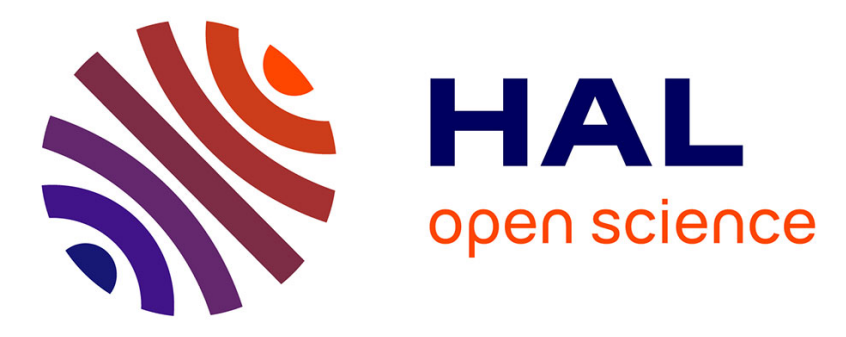

\title{
Phylogenetic signal in bone histology of amniotes revisited.
}

Lucas Legendre, Nathalie Le Roy, Cayetana Martinez-Maza, Laëtitia Montes, Michel Laurin, Jorge Cubo

\section{- To cite this version:}

Lucas Legendre, Nathalie Le Roy, Cayetana Martinez-Maza, Laëtitia Montes, Michel Laurin, et al.. Phylogenetic signal in bone histology of amniotes revisited.. Zoologica Scripta, 2013, 42 (1), pp.44-53. 10.1111/j.1463-6409.2012.00564.x . hal-00781245

\section{HAL Id: hal-00781245 https://hal.science/hal-00781245}

Submitted on 21 Jun 2013

HAL is a multi-disciplinary open access archive for the deposit and dissemination of scientific research documents, whether they are published or not. The documents may come from teaching and research institutions in France or abroad, or from public or private research centers.
L'archive ouverte pluridisciplinaire HAL, est destinée au dépôt et à la diffusion de documents scientifiques de niveau recherche, publiés ou non, émanant des établissements d'enseignement et de recherche français ou étrangers, des laboratoires publics ou privés. 
Corresponding authors

Michel LAURIN

MNHN, bâtiment de géologie. BC 45. 43 rue Buffon, 75005 Paris, France

michel.laurin@upmc.fr

Jorge CUBO

UPMC, Univ. Paris 06, 4 place Jussieu, BC 19, F-75005, Paris, France

jorge.cubogarcia@upmc.fr

\section{Phylogenetic signal in bone histology of amniotes revisited}

by

LUCAS LEGENDRE, NATHALIE LE ROY, CAYETANA MARTINEZ-MAZA, LAETITIA MONTES, MICHEL LAURIN, JORGE CUBO

Running title: Phylogenetic signal in bone histology

L. Legendre et al. 


\section{Abstract}

Legendre, L., Le Roy, N., Martinez-Maza, C., Montes, L., Laurin, M., Cubo, J. (2012). Phylogenetic signal in bone histology of amniotes revisited. Zoologica Scripta 00, 000000. There is curretly a debate about the presence of a phylogenetic signal in bone histological data, but very few rigorous tests have fueled the discussions on this topic. Here we performed new analyses using a larger set of seven histological traits and including 25 taxa (nine extinct and sixteen extant taxa), using three methods: the phylogenetic eigenvector regression, the tree length distribution and the regressions on distance matrices. Our results clearly show that the phylogenetic signal in our sample of bone histological characters is strong, even after correcting for multiple testing. Most characters exhibit a significant phylogenetic signal according to at least one of our three tests, with the phylogeny often explaining 20 to $60 \%$ of the variation in the histological characters. Thus, we conclude that the phylogenetic comparative method should be systematically used in interspecific analyses of bone histodiversity to avoid problems of non-independence among observations.

Corresponding authors: Michel Laurin, CNRS UMR 7207, MNHN, bâtiment de géologie. BC 45.43 rue Buffon, 75005 Paris, France.E-mail : michel.laurin@upmc.fr and Jorge Cubo, UPMC, Univ. Paris 06, UMR 7193, ISTeP, 4 place Jussieu, BC 19, F75005, Paris, France and CNRS, UMR 7193, ISTeP, 4 place Jussieu, BC 19, F-75005, Paris, France. E-mail: jorge.cubo garcia@upmc.fr Lucas Legendre and Laetitia Montes, UPMC, Univ. Paris 06, UMR 7193, ISTeP, 4 placeJussieu, BC 19, F-75005, Paris, France and CNRS, UMR 7193, ISTeP, 4 place Jussieu, BC 19,F-75005, Paris, France.E-mails: lucas.legendre@upmc.fr, laetitia.montes-poloni@live.fr

Nathalie Le Roy, UMR CNRS 6282 Biogeosciences, Univ. Bourgogne, 6 bd Gabriel, Dijon 21000 France. E-mail : Nathalie.Le-Roy@u-bourgogne.fr Cayetana Martinez-Maza, Department of Paleobiology, Museo Nacional de Ciencias Naturales - CSIC, Madrid, Spain.E-mail: martinezmaza.cayetana@gmail.com 


\section{Introduction}

The putative presence of a phylogenetic signal in bone histological data has played a prominent role in the development of paleohistology. Paleohistology was born during the early $\mathrm{XIX}^{\text {th }}$ century with the publication of the first observations of fossil samples (Agassiz 1833, 1844). The history of this discipline contains two welldelimited phases (Cubo and Laurin 2011). During the second half of the XIX ${ }^{\text {th }}$ and the first half of the $\mathrm{XX}^{\text {th }}$ centuries, paleohistologists were mainly interested in problems of taxon determination using fragments of bone tissue (e.g. Queckett 1849a, b, 1855). All these studies assumed that osteohistological variation contains diagnostic information and a phylogenetic signal. In fact, a number of bone histological traits are synapomorphies at different nodes of the vertebrate phylogeny. For instance, the presence of endochondral bone tissue in Osteichthyes (Janvier 1996) or the presence of acellular bone tissue in several teleosts (Meunier 2011). From the second half of the $\mathrm{XX}^{\text {th }}$ century onwards, paleohistologists seemed no longer interested in utilizing bone tissue for systematics, and focused on paleobiology instead. These scientists used bone histological information to infer life history traits of extinct vertebrates, assuming that bone histodiversity is linked to functional parameters (e.g. Enlow \& Brown 1956, 1957, 1958; Ricqlès 1975, 1976, 1977a, b, Sander 2000; Padian et al 2001; Horner et al 2001). This dichotomy between historicism and functionalism is unsatisfactory from a conceptual point of view because a given feature may simultaneously contain a phylogenetic signal (it may constitute a synapomorphy at a given node) and have a functional significance. Desdevises et al. (2003) developed a statistical method allowing to partition the variation of a trait into a phylogenetic component, a functional or ecological component, the covariation between these fractions, and finally an unexplained fraction. Cubo et al. (2005) applied this method to bone microstructural and histological traits and concluded that while phylogenetic signal was highly significant at the microstructural level of organization, it was significant for some histological traits, but not for others. This conclusion has been cited by many authors to argue that "the histological level of organization by itself may reflect at best a weak signal" (Ricqlès et al 2008) and that bone histodiversity mainly reflects functional 
aspects (Buffrénil et al 2008). The aim of this paper is to test the presence of a phylogenetic signal in bone histodiversity of amniotes using a larger set of bone histological traits than previous studies and including extinct as well as extant taxa.

\section{Material and Methods}

\section{Material}

We analyzed the histological data set published by Cubo et al. (2012). It includes information from humeri, femora and tibiae of a sample of 52 specimens belonging to 16 extant species of amniotes, plus the following samples of extinct archosaurs: Postosuchus UCMP 28353 (humerus), Calyptosuchus UCMP 25914 (femur), Rutiodon UCMP 25921 (femur) and Typothorax A269 25905 (femur) among Crurotarsi, and Lesothosaurus QR 3076 (femur), Maiasaura MOR 005 (tibia), Coelophysis AMNH 27435 (tibia), Allosaurus UUVP 3694 (femur) and UUVP 154 (tibia), and Troodon MOR 748 (femur) among Ornithodira.

\section{Methods}

Phylogeny. A reference phylogeny is used in our analyses (Fig. 1). The divergence times are based mostly on fossil evidence. The topology for Testudines follows the established consensus according to which Cryptodira and Pleurodira are sister-taxa, as was established long ago (Gaffney \& Meylan 1988). Our sample includes only three turtle terminal taxa, Trachemys (Emydidae), Pelodiscus (Trionychidae) and Macrochelodina (Pleurodira). For the squamates, the topology was compiled from Estes (1982), Estes et al. (1988), Rieppel (1988) and Caldwell (1999). The placement of Testudines is still controversial (Rieppel \& Reisz 1999; Zardoya \& Meyer 2001); therefore, we placed Testudines as the sister-group of Diapsida, as numerous paleontological studies have argued (Laurin \& Reisz 1995; Lee 2001; Lyson et al 2010). Considering that the oldest known amniote (Hylonomus lyelli) comes from the late Bashkirian (Marjanović \& Laurin 2007), we used a divergence time between mammals and sauropsids (last common ancestor of Amniota) of 310 Ma. Divergence times between lepidosaurs and 
crocodylians (252 Ma) and between crocodiles and birds (last common ancestor of Archosauria, $243 \mathrm{Ma}$ ) were taken from Reisz \& Müller (2004). The last two divergence times are reliable estimates because of the high quality of the fossil record before and after the first occurrence of these taxa (Reisz \& Müller 2004). Divergence time between Lacertidae and Varanidae (189 Ma) and the age of the last common ancestor of dinosaurs (230 Ma) were respectively taken from Evans (2003) and Langer et al. (2010), both obtained from the fossil record. A few divergence times were taken from Pyron (2010), who used a molecular approach calibrated by the four well-constrained fossil dates obtained by Müller \& Reisz (2005). Dates taken from Pyron (2010) include divergence times between Paleognathae and Neognathae (last common ancestor of modern birds, $112 \mathrm{Ma}$ ) and between Anas and Turdus (last common ancestor of Neognathae, $77 \mathrm{Ma})$. These molecular clock estimates are congruent with vicariance biogeography and fossil evidence, respectively (Laurin et al 2012).

Histology and microscopic observation. All histological measures were performed on transverse bone sections $100+/-10 \mu$ m thick, which were made across the diaphysis using a diamond-tip circular saw. Each thin section was ground and polished before being mounted on a side, and then observed using optical microscopy and digital imaging (Eclipse E600POL with a DXM 1200 Digital Eclipse Camera System; Nikon, Japan). Vascular orientation and density were measured with a magnification of 40x, whereas cellular variables were measured with a 400x magnification.

Ontogenetic control. Considering that there is a marked ontogenetic variation of bone histological features mainly linked to bone growth rate, we standardized our data acquisition by measuring bone histological features in regions formed during the phase of sustained high growth rate. Whereas in extant species sampled bone formed at sustained high growth rate is located at the bone periphery (specimens were actively growing when they were euthanized), in our samples from extinct taxa this region is located in the deep cortex (i.e., fossil specimens were ontogenetically older than those belonging to extant species).

\section{Variables}


Vascular orientation. Blood vessels in the bones were lost during sample preparation in extant species, and during the fossilization process in the extinct taxa. Thus, this variable measures the orientation of the cavities (called vascular canals) that contained the blood vessels and associated connective tissues (Fig. 2A, B). The orientation of each vascular cavity was determined using Image $\mathrm{J}$. We inserted the largest ellipse that could fit into each vascular cavity. To improve repeatability, the orientation of each vascular cavity was measured using the radial index published by de Boef \& Larsson (2007). The orientation of these cavities was computed as the angle between the major axis of each ellipse and a vector tangent to bone periphery. Thus, vascular canals running parallel to bone periphery have angles approaching $0^{\circ}$, and those running parallel to the radius of bone cross-section have angles approaching $90^{\circ}$ (de Boef \& Larsson 2007). Vascular canal orientation is a continuously varying trait that we transformed into discrete orientation classes: circular canals $(\mathrm{C})$, which run roughly parallel to the bone periphery $\left(0^{\circ}+22.5^{\circ} ; 180^{\circ}-22.5^{\circ}\right)$; radial canals $(\mathrm{R})$, which run roughly orthogonal to the bone periphery $\left(90^{\circ}+/-22.5^{\circ}\right)$; and oblique canals $(\mathrm{O})$, i.e. those canals excluded from the intervals corresponding to radial canals and to circular ones. These types of vascular orientation are illustrated in de Margerie (2002), de Margerie et al. (2004) and de Boef $\&$ Larsson (2007). We used three variables to describe the major vascular orientations found on each bone section: proportion of circular canals $(\mathrm{C} / \mathrm{C}+\mathrm{R}+\mathrm{O})$, proportion of radial canals $(\mathrm{R} / \mathrm{C}+\mathrm{R}+\mathrm{O})$, and proportion of oblique canals $(\mathrm{O} / \mathrm{C}+\mathrm{R}+\mathrm{O})$. In avascular bones, the proportions of circular, radial and oblique canals were considered as zero.

Vascular density. Vascular density was measured by Cubo et al. (2005) as the ratio of total vascular canal area to primary bone area (Fig. 2C). Here we measured the number of canals divided by $\mathrm{mm}^{2}$ because the osteons are not yet filled in our sample of extant taxa (the individuals were still growing). Sections showing a single vascular canal were considered to be avascular because this single vascular canal most probably corresponds to a blood vessel running from the periosteum to the endosteum (a "canal nourricier" oriented more or less radially). 
Cellular variables. Cellular shape, size and density were carefully measured outside the osteons both in extant taxa (in which osteons are not yet filled because they are still growing) and in extinct taxa (in which osteons are already filled). Like vascular canals, osteocytes were lost during the preparation of bone samples in extant species and during the process of fossilization in extinct taxa (Fig. 2D). Thus, we measured the shape, size, and density of cavities (osteocyte lacunae) that contained bone cells (osteocytes). When possible in extant species (i.e., when the bone section contained enough osteocyte lacunae), we measured 120 osteocyte lacunae for each bone section (i.e. 30 lacunae measured in four areas in each the bone section - rostral, lateral, medial and caudal).

Cellular shape was quantified as the ratio between the major and the minor axes of these cavities $(0<$ shape $\leq 1)$. The lacunae are perfectly circular in the plane of the section when the shape is equal to 1 .

Cellular size was computed using the major and minor axes of osteocyte lacunae and assuming the geometry of an ellipse following the equation $\pi \times L / 2 \times 1 / 2$.

Cellular density was quantified as the number of lacunae divided by the surface of the bone section in $\mathrm{mm}^{2}$.

All measurements were carried out using a microscope focused on a single layer of osteocyte lacunae. Thus, the measurements refer to a single layer of osteocyte lacunae whatever the thickness of the ground section. Cellular density was computed including all osteocyte lacunae of the selected single layer. Following Organ et al. (2007), only the largest osteocyte lacunae included in this layer were measured to compute cell size and shape, to ensure that cell lacunae were measured near the middle of their longitudinal axis.

\section{Phylogenetic comparative methods}

Three methods were used to test for phylogenetic signal. Obtained results were corrected for multiple testing.

Phylogenetic eigenvector regression. The phylogeny of our sample of amniotes (Fig. 1) was expressed in the form of principal coordinates (Diniz-Filho et al 1998) to be used as explanatory variables in tests of phylogenetic signal. Considering that we obtained as many principal coordinate axes as terminal taxa included in the analyses, a 
selection procedure was necessary. We retained and used the phylogenetic principal coordinate axes significantly related to the dependent variable as explanatory variables (Desdevises et al 2003).

Regressions on Distance Matrices. This method was described by Mantel (1967). Firstly we computed pairwise phylogenetic (patristic) distances using the consensus phylogeny (Fig. 1). For each pair of species, the histological dissimilarity was quantitatively assessed using the absolute value of the difference between the character values. Two distance matrices were constructed: the phylogenetic distance matrix (the sum of branch lengths connecting two taxa, in Myr) and the histological dissimilarity matrix. Afterwards, the histological dissimilarity (the dependent variable) was regressed on the phylogenetic distance (the independent variable). The significance of the regression coefficient could not be tested using a parametric test because the values of the phylogenetic distance matrices (the independent variables) are not normally distributed, and a normal distribution is a fundamental condition of parametric testing. In these cases, significance of statistics must be tested through randomization tests (Harvey \& Pagel 1991: 152-155). Therefore, the significance of the $\left(\mathrm{R}^{2}\right)$ parameter was tested by a permutation test (Mantel 1967) using Permute 3.4a9 (Casgrain 2005), a software that can perform regressions on distance matrices as described by Legendre $e t$ al. (1994). Each regression and its statistics were recomputed 9999 times by repeatedly randomizing the values of the histological dissimilarity matrix to obtain a null distribution against which to test the significance of the statistics of the regression on the original dataset.

Random Squared Tree_Length Distribution. A phylogenetic signal can also be detected in a character by determining if the character requires fewer steps on the reference phylogeny than on most randomly generated trees, provided that the phylogeny has been produced using other characters. In the case of continuous characters, squared length (rather than number of steps) of the character over the tree can be used (Maddison 1991). The squared length is the most appropriate statistic for a continuous character. It is the sum of the square of changes between each node or between nodes and terminal taxa. Squared change parsimony minimizes this statistic, and in the version that we used (weighted square-change parsimony, implemented in Mesquite), what is minimized is the sum over all branches of the squared change 
divided by branch length (Maddison, 1991). The probability that the character values is distributed randomly with respect to the phylogeny is simply the proportion of random trees in which squared length is equal or less than on the reference tree. These simulations were performed by the TreeFarm package of modules of Mesquite (Maddison \& Maddison 2011; Maddison et al 2011). The appropriate procedure is to randomly permute the taxa (along with their character values) on the tree, while holding the topology as well as the branch lengths constant (Laurin 2004). This procedure has the advantage of yielding random trees that have a branch length distribution identical to that of the reference tree. This is necessary because the squared length of a character over a tree depends on tree depth (Maddison 1991).

All these tests were performed for our whole sample (Amniota), as well as for three nested sub-groups: Sauropsida, Diapsida, and Archosauria. We could not test other subsets of our sampled taxa because the sample size would have been insufficient, resulting in very low power and hence, meaningless negative results.

Corrections for multiple testing. Given that we have seven characters, three bones, three tests, , and four nested clades on which these tests were applied, we have performed 252 tests. Thus, corrections for multiple testing are required because at the customary 0.05 probability threshold, three false positives are expected. For this purpose, we have used the False Discovery Rate (FDR) analysis, which is reasonably easy to use and powerful, as it retains more significant results than classical Bonferroni corrections (Berjamini \& Hochbert 1995; Curran-Everett 2000). This is why we have used it in our recent papers that included multiple tests (e.g. Laurin et al 2009).

\section{Results}

Most histological traits exhibit a significant phylogenetic signal according to at least one of our three tests (Table 1), at least for Amniota (15 bone by character combinations, out of 21 , yielded significant results even after correction for multiple testing). For smaller, nested clades, the number of significant results was lower, presumably reflecting decreased power with a lower taxonomic sample size because the number of significant results is directly proportional to the number of included taxa (significant results for 12 bone by character combinations out of 21 for Sauropsida, but 
only 10 for Diapsida and 4 for Archosauria). Among these traits, only femoral cell density becomes non-significant (with any of the three methods) among femoral variables after correction for multiple testing (False Discovery Rate analysis; Table 1). The probabilities yielded by tree length distribution on tibia were higher than those obtained from phylogenetic eigenvector regression or regressions on distance matrices (Table 1). Of the 34 probabilities that were $<0.05$ when taken in isolation, 26 remain significant after FDR analysis.

Bone histological variation explained by the phylogeny is in the order of 20$60 \%$, as shown by the phylogenetic eigenvector regression analysis (Table 2, first column). Variation explained by the phylogeny obtained using regressions on distance matrices are lower, as expected, because this method underestimates the real values, as Legendre (2000) showed using simulations. Here, the regression coefficients obtained using phylogenetic eigenvector regression are always much higher than those obtained using regressions on distance matrices (Table 2), which is congruent with the findings of Legendre (2000).

\section{Discussion}

Mayr (1961) separates evolutionary biology (concerning historical, or ultimate, causation) from functional biology (tackling immediate, or proximate, causation). The nature of the evidence is comparative in evolutionary biology, whilst it is typically experimental in functional biology. Within evolutionary biology, systematists and functional morphologists are interested in different patterns. For the former, interested in the reconstruction of phylogenetic patterns, the functional adaptation to current conditions (autapomorphies) may mask a pure phylogenetic signal. For example, the autapomorphic flightless condition of the Galapagos cormoran is associated with a whole array of morphological changes (Cubo and Casinos, 1997) that may mask synapomorphies of more inclusive nodes (e.g. Phalacrocoracidae). For functional morphologists, phylogenetic patterns are factors that may explain why organisms do not appear to have reached optimal adaptation to current conditions. In « The shadow of forgotten ancestors differently constrains the fate of Alligatoroidea and Crocodyloidea » 
Piras et al. (2009) suggest that the phylogenetic inheritance of a clade may determine its evolutionary fate. According to Seilacher (1970), a third set of factors (in addition to history and function) may contribute to explain evolutionary patterns: the properties inherent in the materials found in organs and their self-organization properties (with few genetic inputs). These three perspectives are not necessarily mutually exclusive.

In the field of bone biology, Cubo et al. (2005) found a significant phylogenetic signal at the microanatomical level of bone organization, but concluded that the histological level contained a lower signal. However, considering that Cubo et al. (2008, 2012) showed evidence for a significant phylogenetic signal in the variation of bone growth rate in amniotes, and that, according to Amprino's rule, bone histodiversity may reflect variation in bone growth rates (Amprino 1947; Montes et al 2010), we expected that bone histological variation contained a significant phylogenetic signal. Here we expand upon the analyses initiated by Cubo et al. (2005) using a larger set of histological traits and including extinct taxa.

Our results clearly show that the phylogenetic signal in the bone histological characters that we studied is strong, with the phylogeny often explaining 20 to $60 \%$ of the variation in the histological characters. The proportion of significant results appears to depend rather strongly on taxonomic sample size, reflecting the common and expected increased power at larger sample sizes. Nevertheless, our results do not imply that functional factors are unimportant. In fact, some of the variation explained by the phylogeny may represent covariation with functional factors (rather than purely phylogenetic variation), although variation partition analyses would be required to determine this. These are beyond the scope of this study, as they would require additional data (such as growth rate, metabolic rate, etc.). However, some evidence suggests that part of this phylogenetic signal represents covariation with functional factors, at least for the femur. Cubo et al. (2012) constructed a paleobiological inference model using extant taxa for estimating bone growth rate of extinct taxa (a functional factor according to Amptino's rule) from bone histological data. The response variable (i.e. the functional variable, bone growth rate) was significantly correlated with, and could be reliably inferred from predictor variables (bone histological traits). These results are evidence of a significant functional effect on bone histological variation, and are complementary to the evidence presented in this study for a significant phylogenetic 
signal on the same traits. We conclude that, in view of the results reported above, the phylogenetic comparative method should be used in any study dealing with the interspecific variation of bone histology to avoid problems of non-independence among observations. This is unfortunately still not common practice. Some disciplines such as ecology and, to a lesser extent, vertebrate morphology, incorporated the phylogenetic comparative method soon after the initial development of this approach in the middle of the 1980s (see a review in Harvey \& Pagel 1991). In contrast, the use of these methods is not yet generalized in other fields such as bone histology (e.g. de Buffrénil et al 2008), but we hope that this study will help motivate bone histologists to adopt these methods.

\section{Acknowledgements}

This study was funded by the grants CGL2011-23919 and CGL2010-15243 of the Spanish Government (to JC), the JAE-Doc program CSIC, cofunded by FSE (to CMM), and by the CNRS and the French ministry of research (operating grants of UMR 7207 for ML and 7193 for LL, LM and JC).

\section{References}

Benjamini, Y. \& Hochberg, Y. (1995). Controlling the false discovery rate: a practical and powerful approach to multiple testing. Journal of the Royal Statistical Society. Series B (Methodological), 57, 289-300.

Benjamini, Y. \& Hochberg, Y. (1995). Controlling the false discovery rate: a practical and powerful approach to multiple testing. Journal of the Royal Statistical Society. Series B (Methodological), 57, 289-300.

de Boef, M \& Larsson, H. C. E. (2007). Bone microstructure: quantifying bone vascular orientation. Canadian Journal of Zoology, 85, 63-70.

Bourdon, E., de Ricqlès, A. \& Cubo, J. (2009). A new Transantarctic relationship: morphological evidence for a Rheidae-Dromaiidae-Casuariidae clade (Aves, Palaeognathae, Ratitae). Zoological Journal of the Linnean Society, 156, 641663. 
de Buffrénil, V., Houssaye, A. \& Böhme, W. (2008). Bone vascular supply in monitor lizards (Squamata: Varanidae): influence of size, growth, and phylogeny. Journal of Morphology, 269, 533-543.

Caldwell, M. W. (1999). Squamate phylogeny and the relationships of snakes and mosasauroids. Zoological Journal of the Linnean Society, 125, 115-147.

Casgrain, P. (2005). Permute! Available at http://www.bio.umontreal.ca/Casgrain/en/labo/permute/index.html

Chatterjee, S. (2002) The morphology and systematics of Polarornis, a cretaceous loon (Aves: Gaviidae) from Antarctica. In Z. Zhou, \& F. Zhang (Eds) Proceedings of the 5th Symposium of the Society of Avian Paleontology and Evolution (pp. 125155) Beijing: Science Press.

Clarke, J. A., Tambussi, C. P., Noriega, J. I., Erickson, G. M. \& Ketcham, R. A. (2005). Definitive fossil evidence for the extant avian radiation in the Cretaceous. Nature, 433, 305-308.

Cubo, J. \& Casinos, A. (1997). Flightlessness and long bone allometry in Palaeognathiformes and Sphenisciformes. Netherlands Journal of Zoology, 47, 209-226.

Cubo, J., Legendre, P., de Ricqlès, A., Montes, L., de Margerie, E., Castanet, J. \& Desdevises, Y. (2008). Phylogenetic, functional, and structural components of variation in bone growth rate of amniotes. Evolution \& Development, 10, $217-$ 227.

Cubo, J., Ponton, F., Laurin, M., de Margerie, E. \& Castanet, J. (2005). Phylogenetic signal in bone microstructure of sauropsids. Systematic Biology, 54, 562-574.

Cubo, J. \& Laurin, M. (2011). Perspectives on vertebrate evolution: topics and problems. Comptes rendus Palevol, 10, 285-292.

Cubo, J., Le Roy, N., Martinez-Maza, C. \& Montes, L. (2012). Paleohistological estimation of bone growth rate in extinct archosaurs. Paleobiology, 38, 335-349.

Curran-Everett, D. (2000). Multiple comparisons: philosophies and illustrations. American Journal of Physiology - Regulatory Integrative and Comparative Physiology, 279, 1-8.

Desdevises, Y., Legendre, P., Azouzi, L. \& Morand, S. (2003). Quantifying phylogenetically structured environmental variation. Evolution, 57, 2467-2652. 
Diniz-Filho, J. A. F., de Sant'Ana, C. E. R. \& Bini, L. M. (1998). An eigenvector method for estimating phylogenetic inertia. Evolution, 52, 1247-1262.

Enlow, D. H. \& Brown, S. O. (1956). A comparative histological study of fossil and recent bone tissues. Part I. Texas Journal of Science, 8, 405-443.

Enlow, D. H. \& Brown, S. O. (1957). A comparative histological study of fossil and recent bone tissues. Part II. Texas Journal of Science, 9, 186-214.

Enlow, D. H. \& Brown, S. O. (1958). A comparative histological study of fossil and recent bone tissues. Part III. The Texas Journal of Science, 10, 187-230.

Estes, R. (1982). The Fossil Record and Early Distribution of Lizards In A. G. J. Rhodin \& K. Miyata (Eds) Advances in Herpetology and Evolutionary Biology: Essays in honor of E. E. Williams (pp. 365-398). Cambridge: Harvard University Press.

Estes, R., de Queiroz, K. \& Gauthier, J. (1988). Phylogenetic Relationships within Squamata. In R. Estes \& G. Pregill (Eds) Phylogenetic Relationships of the Lizard Families (pp. 119-281). Stanford: Stanford University Press.

Evans, S. E. (2003). At the feet of the dinosaurs: the early history and radiation of lizards. Biological Reviews, 78, 513-551.

Gaffney, E. S. \& Meylan, P. A. (1988). A phylogeny of turtles. In M. J. Benton (Ed) The Phylogeny and Classification of the Tetrapods (pp. 157-219). Oxford: Clarendon Press.

Harvey, P. H. \& Pagel, M. D. (1991). The Comparative Method in Evolutionary Biology. Oxford: Oxford University Press.

Hope, S. (2002). The mesozoic radiation of Neornithes. In L. M. Chiappe \& L. M. Witmer (Eds) Mesozoic Birds: Above the Heads of Dinosaurs (pp. 339-388). Berkeley: University of California Press.

Horner, J. R., Padian, K. \& de Ricqlès, A. (2001). Comparative osteohistology of some embryonic and perinatal archosaurs: developmental and behavioral implications for dinosaurs. Paleobiology, 27, 39-58.

Janvier, P. (1996). Early vertebrates. Oxford: Oxford University Press.

Langer, M. C., Ezcurra, M. D., Bittencourt, J. S. \& Novas, F. E. (2010). The origin and early evolution of dinosaurs. Biological Reviews, 85, 55-110.

Laurin, M. \& Reisz, R. R. (1995). A reevaluation of early amniote phylogeny. Zoological Journal of the Linnean Society, 113, 165-223. 
Laurin, M. (2004). The evolution of body size, Cope's rule and the origin of amniotes. Systematic Biology, 53, 594-622.

Laurin, M., Canoville, A. \& Quilhac, A. (2009). Use of paleontological and molecular data in supertrees for comparative studies: the example of lissamphibian femoral microanatomy. Journal of Anatomy, 215, 110-123.

Laurin, M., Gussekloo, S. W. S., Marjanovic, D., Legendre, L. \& Cubo, J. (2012). Testing gradual and speciational models of evolution in extant taxa: the example of ratites. Journal of Evolutionary Biology, 25, 293-303.

Lee, M. S. Y. (2001). Molecules, morphology, and the monophyly of diapsid reptiles. Contributions to Zoology, 70, 1-18.

Legendre, P., Lapointe, F.-J. \& Casgrain, P. (1994). Modeling brain evolution from behavior: a permutational regression approach. Evolution. International Journal of Organic Evolution, 48, 1487-1499.

Legendre, P. (2000). Comparison of permutation methods for the partial correlation and partial Mantel tests. Journal of Statistical Computation and Simulation, 67, $37-73$.

Lyson, T. R., Bever, G. S., Bhullar, B.-A. S., Joyce, W. G. \& Gauthier, J. A. (2010). Transitional fossils and the origin of turtles. Biology Letters, 6, 830-833.

Maddison, W. P. (1991). Squared-change parsimony reconstructions of ancestral states for continuous-valued characters on a phylogenetic tree. Systematic Zoology, 40, 304-314.

Maddison, W. P. \& Maddison, D. R. (2011). Mesquite: a modular system for evolutionary analysis. Version 2.75. http://mesquiteproject.org.

Maddison, W. P. \& Maddison, D. R. (2011). TreeFram package of modules for Mesquite. Version 2.75. http://mesquiteproject.org.

Mantel, N. (1967). The detection of disease clustering and a generalized regression approach. Cancer Research, 27, 209-220.

de Margerie, E. (2002). Laminar Bone as an adaptation to torsional loads in flapping flight. Journal of Anatomy, 201, 521-526.

de Margerie, E., Robin, J.-P., Verrier, D., Cubo, J., Groscolas, R. \& Castanet, J. (2004). Assessing a relationship between bone microstructure and growth rate: a fluorescent labeling study in the king penguin chick (Aptenodytes patagonicus). The Journal of Experimental Biology, 207, 869-879. 
Marjanović, D. \& Laurin, M. (2007). Fossils, molecules, divergence times, and the origin of lissamphibians. Systematic Biology, 56, 369-388.

Meunier, F. J. (2011). The Osteichtyes, from the Paleozoic to the extant time, through histology and palaeohistology of bony tissues. Comptes Rendus Palevol, 10, $347-355$.

Müller, J. \& Reisz, R. R. (2005). Four well-constrained calibration points from the vertebrate fossil record for molecular clock estimates. BioEssays, 27, 10691075.

Olson, S. L. \& Parris, D. C. (1987). The Cretaceous birds of New Jersey. Smithsonian Contributions to Paleobiology, 63, 1-22.

Organ, C. L., Shedlock, A. M., Meade, A., Pagel, M. \& Edwards, S. V. (2007). Origin of avian genome size and structure in non-avian dinosaurs. Nature, 446, 180184.

Padian, K., de Ricqlès, A. \& Horner, J. R. (2001). Dinosaurian growth rates and bird origins. Nature, 412, 405-408.

Piras, P., Teresi, L., Buscalioni, A. D., Cubo, J. (2009). The shadow of forgotten ancestors differently constrains the fate of Alligatoroidea and Crocodyloidea. Global Ecology and Biogeography, 18, 30-40.

Pyron, R. A. (2010). A likelihood method for assessing molecular divergence time estimates and the placement of fossil calibrations. Systematic Biology, 59, 185194.

Quecket, J. (1849a). On the intimate structure of bone as composing the skeleton in the four great classes of animals viz., mammals, birds, reptiles and fishes, with some remarks on the great value of the knowledge of such structure in determining the affinities of minute fragments of organic remains. Transactions of the Royal Microscopy Society of London, 2, 46-58.

Quecket, J. (1849b). Additional observations on the intimate structure of bone. Transactions of the Royal Microscopy Society of London, 2, 40-42.

Quecket, J. (1855). Descriptive and illustrated catalogue of the histological series contained in the Museum of the Royal College of Surgeons of London. Volume 2. London.

Reisz, R. R. \& Müller, J. (2004). Molecular timescales and the fossil record: a 
paleontological perspective. Trends in Genetics, 20, 237-241.

de Ricqlès, A. (1975). Recherches paléohistologiques sur les os longs des tétrapodes VII. - Sur la classification, la signification fonctionnelle et l'histoire des tissus osseux des tétrapodes. Première partie. Annales de Paléontologie, 61, 51-129. de Ricqlès, A. (1976). Recherches paléohistologiques sur les os longs des tétrapodes VII. - Sur la classification, la signification fonctionnelle et l'histoire des tissus osseux des tétrapodes. Deuxième partie. Annales de Paléontologie, 62, 71-126. de Ricqlès, A. (1977a). Recherches paléohistologiques sur les os longs des tétrapodes VII. - Sur la classification, la signification fonctionnelle et l'histoire des tissus osseux des tétrapodes. Deuxième partie, suite. Annales de Paléontologie, 63, 3356.

de Ricqlès, A. (1977b). Recherches paléohistologiques sur les os longs des tétrapodes VII. - Sur la classification, la signification fonctionnelle et l'histoire des tissus osseux des tétrapodes. Deuxième partie, fin. Annales de Paléontologie, 63, 133160.

de Ricqlès, A., Padian, K., Knoll, F. \& Horner, J. R. (2008). On the origin of high growth rates in archosaurs and their ancient relatives: complementary histological studies on Triassic archosauriforms and the problem of a "phylogenetic signal" in bone histology. Annales de Paléontologie, 94, 57-76.

Rieppel, O. (1988). The classification of the Squamata. In M. J. Benton (Ed) The Phylogeny and Classification of the Tetrapods (pp. 261-293). Oxford: Clarendon Press.

Rieppel, O. \& Reisz, R. R. (1999). The origin and early evolution of turtles. Annual Review of Ecology and Systematics, 30, 1-22.

Sander, P. M. (2000). Longbone histology of the Tendaguru sauropods: implications for growth and biology. Paleobiology, 26, 466-488.

Scotese, C. R. (2001). Paleomap Project. http://www.scotese.com

Zardoya, R. \& Meyer, A. (2001). The evolutionary position of turtles revised.

Naturwissenschaften, 88, 193-200. 


\section{Tables}

\begin{tabular}{|c|c|c|c|c|c|}
\hline Bone & Histological traits & & $\mathrm{n}$ & $\begin{array}{l}\text { Phylogenetic } \\
\text { eigenvector } \\
\text { regression }\end{array}$ & $\begin{array}{l}\text { Tree } \\
\text { length } \\
\text { distribution }\end{array}$ \\
\hline \multirow[t]{28}{*}{ Femur } & \multirow[t]{4}{*}{ Cell density } & Amniota & 22 & - & 0.023 \\
\hline & & Sauropsida & 19 & $0.0002 *$ & 0.020 \\
\hline & & Diapsida & 16 & $0.002 *$ & 0.023 \\
\hline & & Archosauria & 12 & 0.040 & 0.110 \\
\hline & \multirow[t]{4}{*}{ Cell size } & Amniota & 22 & $0.020 *$ & $0.0009 *$ \\
\hline & & Sauropsida & 19 & - & $0.0006^{*}$ \\
\hline & & Diapsida & 16 & - & $0.0006 *$ \\
\hline & & Archosauria & 12 & $0.011^{*}$ & $0.003 *$ \\
\hline & \multirow[t]{4}{*}{ Cell shape } & Amniota & 22 & $0.012 *$ & $0.014^{*}$ \\
\hline & & Sauropsida & 19 & 0.026 & 0.019 \\
\hline & & Diapsida & 16 & 0.047 & 0.038 \\
\hline & & Archosauria & 12 & - & 0.056 \\
\hline & \multirow[t]{4}{*}{ Vascular radial orientation } & Amniota & 22 & $0.015^{*}$ & 0.047 \\
\hline & & Sauropsida & 19 & $0.004 *$ & 0.050 \\
\hline & & Diapsida & 16 & $0.003 *$ & 0.025 \\
\hline & & Archosauria & 12 & - & 0.897 \\
\hline & \multirow[t]{4}{*}{ Vascular oblique orientation } & Amniota & 22 & $0.001 *$ & 0.085 \\
\hline & & Sauropsida & 19 & - & 0.255 \\
\hline & & Diapsida & 16 & - & 0.560 \\
\hline & & Archosauria & 12 & $0.007 *$ & 0.221 \\
\hline & \multirow[t]{4}{*}{ Vascular circular orientation } & Amniota & 22 & $0.010 *$ & $<0.0001 *$ \\
\hline & & Sauropsida & 19 & $0.0001 *$ & $0.0001 *$ \\
\hline & & Diapsida & 16 & $0.0001 *$ & $0.0008 *$ \\
\hline & & Archosauria & 12 & - & 0.578 \\
\hline & \multirow[t]{4}{*}{ Vascular density } & Amniota & 22 & $0.001 *$ & $0.0002 *$ \\
\hline & & Sauropsida & 19 & $0.0001 *$ & $0.0002 *$ \\
\hline & & Diapsida & 16 & $0.0002 *$ & $0.001 *$ \\
\hline & & Archosauria & 12 & 0.062 & 0.028 \\
\hline \multirow[t]{13}{*}{ Humerus } & \multirow[t]{4}{*}{ Cell density } & Amniota & 17 & - & 0.154 \\
\hline & & Sauropsida & 14 & $0.002 *$ & 0.161 \\
\hline & & Diapsida & 11 & 0.014 & 0.165 \\
\hline & & Archosauria & 7 & 0.054 & 0.119 \\
\hline & \multirow[t]{4}{*}{ Cell size } & Amniota & 17 & $0.002 *$ & 0.140 \\
\hline & & Sauropsida & 14 & $0.010^{*}$ & 0.106 \\
\hline & & Diapsida & 11 & 0.037 & 0.084 \\
\hline & & Archosauria & 7 & - & 0.598 \\
\hline & \multirow[t]{4}{*}{ Cell shape } & Amniota & 17 & - & $0.006^{*}$ \\
\hline & & Sauropsida & 14 & $0.0003 *$ & $0.004 *$ \\
\hline & & Diapsida & 11 & $0.0009 *$ & $0.004 *$ \\
\hline & & Archosauria & 7 & 0.037 & 0.046 \\
\hline & Vascular radial orientation & Amniota & 17 & $0.008 *$ & 0.870 \\
\hline
\end{tabular}




\begin{tabular}{|c|c|c|c|c|c|}
\hline & \multirow{6}{*}{ Vascular oblique orientation } & \multirow{2}{*}{$\begin{array}{l}\text { Sauropsida } \\
\text { Diapsida }\end{array}$} & \multirow{2}{*}{$\begin{array}{l}14 \\
11\end{array}$} & - & 0.818 \\
\hline & & & & - & 0.768 \\
\hline & & Archosauria & 7 & - & 0.897 \\
\hline & & Amniota & 17 & $0.003 *$ & 0.043 \\
\hline & & Sauropsida & 14 & - & 0.070 \\
\hline & & Diapsida & 11 & - & 0.051 \\
\hline & & Archosauria & 7 & 0.050 & 0.942 \\
\hline & \multirow[t]{4}{*}{ Vascular circular orientation } & Amniota & 17 & - & $0.005 *$ \\
\hline & & Sauropsida & 14 & $0.0003 *$ & $0.007 *$ \\
\hline & & Diapsida & 11 & $0.0002 *$ & $0.005^{*}$ \\
\hline & & Archosauria & 7 & 0.050 & 0.713 \\
\hline & \multirow[t]{4}{*}{ Vascular density } & Amniota & 17 & - & $0.012 *$ \\
\hline & & Sauropsida & 14 & $0.001 *$ & 0.018 \\
\hline & & Diapsida & 11 & $0.009 *$ & $0.013 *$ \\
\hline & & Archosauria & 7 & - & 0.248 \\
\hline \multirow[t]{28}{*}{ Tibia } & \multirow[t]{4}{*}{ Cell density } & Amniota & 19 & - & 0.505 \\
\hline & & Sauropsida & 16 & - & 0.480 \\
\hline & & Diapsida & 13 & - & 0.581 \\
\hline & & Archosauria & 9 & - & 0.834 \\
\hline & \multirow[t]{4}{*}{ Cell size } & Amniota & 19 & 0.045 & 0.388 \\
\hline & & Sauropsida & 16 & - & 0.472 \\
\hline & & Diapsida & 13 & - & 0.295 \\
\hline & & Archosauria & 9 & - & 0.205 \\
\hline & \multirow[t]{4}{*}{ Cell shape } & Amniota & 19 & 0.073 & 0.283 \\
\hline & & Sauropsida & 16 & - & 0.298 \\
\hline & & Diapsida & 13 & - & 0.289 \\
\hline & & Archosauria & 9 & - & 0.138 \\
\hline & \multirow[t]{4}{*}{ Vascular radial orientation } & Amniota & 19 & - & 0.839 \\
\hline & & Sauropsida & 16 & - & 0.860 \\
\hline & & Diapsida & 13 & - & 0.872 \\
\hline & & Archosauria & 9 & - & 0.483 \\
\hline & \multirow[t]{4}{*}{ Vascular oblique orientation } & Amniota & 19 & $0.007 *$ & 0.396 \\
\hline & & Sauropsida & 16 & $0.004 *$ & 0.463 \\
\hline & & Diapsida & 13 & 0.042 & 0.624 \\
\hline & & Archosauria & 9 & - & 0.614 \\
\hline & \multirow[t]{4}{*}{ Vascular circular orientation } & Amniota & 19 & 0.037 & $0.0007 *$ \\
\hline & & Sauropsida & 16 & $0.002 *$ & $0.0002 *$ \\
\hline & & Diapsida & 13 & $0.001 *$ & $0.0005 *$ \\
\hline & & Archosauria & 9 & - & 0.393 \\
\hline & \multirow[t]{4}{*}{ Vascular density } & Amniota & 19 & - & 0.803 \\
\hline & & Sauropsida & 16 & - & 0.746 \\
\hline & & Diapsida & 13 & - & 0.683 \\
\hline & & Archosauria & 9 & - & 0.933 \\
\hline
\end{tabular}


Table 1. Probability that the observed covariation between the histological data and the phylogeny is random. This is obtained using phylogenetic eigenvector regression, tree length distribution, and regressions from distance matrices. Phylogenetic signal is considered as significant at a 0.05 threshold when taken in isolation. However, only the $\mathrm{P}$ values marked with asterisks are still significant after correction for multiple testing (False Discovery Rate analysis). These data are available as Mesquite Nexus files in the supplementary materials (SOM 1-3). 


\begin{tabular}{|c|c|c|c|c|c|}
\hline Bone & Histological traits & & $\mathrm{n}$ & $\begin{array}{l}\text { Phylogenetic } \\
\text { eigenvector } \\
\text { regression }\end{array}$ & $\begin{array}{l}\text { Regressions } \\
\text { from } \\
\text { distance } \\
\text { matrices }\end{array}$ \\
\hline \multirow[t]{28}{*}{ Femur } & \multirow[t]{4}{*}{ Cell density } & Amniota & 22 & - & 0.001 \\
\hline & & Sauropsida & 19 & 0.666 & 0.005 \\
\hline & & Diapsida & 16 & 0.676 & 0.038 \\
\hline & & Archosauria & 12 & 0.327 & 0.073 \\
\hline & \multirow[t]{4}{*}{ Cell size } & Amniota & 22 & 0.247 & 0.024 \\
\hline & & Sauropsida & 19 & - & 0.004 \\
\hline & & Diapsida & 16 & - & 0.011 \\
\hline & & Archosauria & 12 & 0.397 & 0.077 \\
\hline & \multirow[t]{4}{*}{ Cell shape } & Amniota & 22 & 0.378 & 0.000 \\
\hline & & Sauropsida & 19 & 0.258 & 0.005 \\
\hline & & Diapsida & 16 & 0.252 & 0.0007 \\
\hline & & Archosauria & 12 & - & 0.003 \\
\hline & \multirow{4}{*}{ Vascular radial orientation } & Amniota & 22 & 0.247 & 0.028 \\
\hline & & Sauropsida & 19 & 0.834 & 0.071 \\
\hline & & Diapsida & 16 & 0.818 & 0.176 \\
\hline & & Archosauria & 12 & - & 0.004 \\
\hline & \multirow[t]{4}{*}{ Vascular oblique orientation } & Amniota & 22 & 0.576 & 0.022 \\
\hline & & Sauropsida & 19 & - & 0.012 \\
\hline & & Diapsida & 16 & - & 0.0008 \\
\hline & & Archosauria & 12 & 0.536 & 0.002 \\
\hline & \multirow[t]{4}{*}{ Vascular circular orientation } & Amniota & 22 & 0.286 & 0.117 \\
\hline & & Sauropsida & 19 & 0.908 & 0.250 \\
\hline & & Diapsida & 16 & 0.945 & 0.438 \\
\hline & & Archosauria & 12 & - & 0.0001 \\
\hline & \multirow[t]{4}{*}{ Vascular density } & Amniota & 22 & 0.598 & 0.024 \\
\hline & & Sauropsida & 19 & 0.775 & 0.061 \\
\hline & & Diapsida & 16 & 0.811 & 0.438 \\
\hline & & Archosauria & 12 & 0.307 & 0.077 \\
\hline \multirow[t]{13}{*}{ Humerus } & \multirow[t]{4}{*}{ Cell density } & Amniota & 17 & - & 0.002 \\
\hline & & Sauropsida & 14 & 0.767 & 0.025 \\
\hline & & Diapsida & 11 & 0.656 & 0.107 \\
\hline & & Archosauria & 7 & 0.527 & 0.355 \\
\hline & \multirow[t]{4}{*}{ Cell size } & Amniota & 17 & 0.582 & 0.021 \\
\hline & & Sauropsida & 14 & 0.585 & 0.002 \\
\hline & & Diapsida & 11 & 0.408 & 0.001 \\
\hline & & Archosauria & 7 & - & 0.059 \\
\hline & \multirow[t]{4}{*}{ Cell shape } & Amniota & 17 & - & 0.037 \\
\hline & & Sauropsida & 14 & 0.857 & 0.132 \\
\hline & & Diapsida & 11 & 0.813 & 0.370 \\
\hline & & Archosauria & 7 & 0.609 & 0.431 \\
\hline & Vascular radial orientation & Amniota & 17 & 0.482 & 0.001 \\
\hline
\end{tabular}




\begin{tabular}{|c|c|c|c|c|c|}
\hline & \multirow{6}{*}{ Vascular oblique orientation } & \multirow{2}{*}{$\begin{array}{l}\text { Sauropsida } \\
\text { Diapsida }\end{array}$} & \multirow{2}{*}{$\begin{array}{l}14 \\
11\end{array}$} & - & 0.0002 \\
\hline & & & & - & 0.014 \\
\hline & & Archosauria & 7 & - & 0.146 \\
\hline & & Amniota & 17 & 0.57 & 0.031 \\
\hline & & Sauropsida & 14 & - & 0.017 \\
\hline & & Diapsida & 11 & - & 0.038 \\
\hline & & Archosauria & 7 & 0.798 & 0.067 \\
\hline & \multirow[t]{4}{*}{ Vascular circular orientation } & Amniota & 17 & - & 0.027 \\
\hline & & Sauropsida & 14 & 0.764 & 0.061 \\
\hline & & Diapsida & 11 & 0.886 & 0.247 \\
\hline & & Archosauria & 7 & 0.608 & 0.004 \\
\hline & \multirow[t]{4}{*}{ Vascular density } & Amniota & 17 & - & 0.003 \\
\hline & & Sauropsida & 14 & 0.613 & 0.021 \\
\hline & & Diapsida & 11 & 0.625 & 0.136 \\
\hline & & Archosauria & 7 & - & 0.031 \\
\hline \multirow{28}{*}{ Tibia } & \multirow[t]{4}{*}{ Cell density } & Amniota & 19 & - & 0.033 \\
\hline & & Sauropsida & 16 & - & 0.008 \\
\hline & & Diapsida & 13 & - & 0.029 \\
\hline & & Archosauria & 9 & - & 0.002 \\
\hline & \multirow[t]{4}{*}{ Cell size } & Amniota & 19 & 0.215 & 0.033 \\
\hline & & Sauropsida & 16 & - & 0.038 \\
\hline & & Diapsida & 13 & - & 0.004 \\
\hline & & Archosauria & 9 & - & 0.017 \\
\hline & \multirow[t]{4}{*}{ Cell shape } & Amniota & 19 & 0.179 & 0.013 \\
\hline & & Sauropsida & 16 & - & 0.008 \\
\hline & & Diapsida & 13 & - & 0.007 \\
\hline & & Archosauria & 9 & - & 0.002 \\
\hline & \multirow[t]{4}{*}{ Vascular radial orientation } & Amniota & 19 & - & 0.014 \\
\hline & & Sauropsida & 16 & - & 0.002 \\
\hline & & Diapsida & 13 & - & 0.021 \\
\hline & & Archosauria & 9 & - & 0.011 \\
\hline & \multirow[t]{4}{*}{ Vascular oblique orientation } & Amniota & 19 & 0.308 & 0.034 \\
\hline & & Sauropsida & 16 & 0.058 & 0.559 \\
\hline & & Diapsida & 13 & 0.295 & 0.072 \\
\hline & & Archosauria & 9 & - & 0.014 \\
\hline & \multirow[t]{4}{*}{ Vascular circular orientation } & Amniota & 19 & 0.219 & 0.013 \\
\hline & & Sauropsida & 16 & 0.067 & 0.539 \\
\hline & & Diapsida & 13 & 0.676 & 0.234 \\
\hline & & Archosauria & 9 & - & 0.004 \\
\hline & \multirow[t]{4}{*}{ Vascular density } & Amniota & 19 & - & 0.094 \\
\hline & & Sauropsida & 16 & - & 0.077 \\
\hline & & Diapsida & 13 & - & 0.043 \\
\hline & & Archosauria & 9 & - & 0.060 \\
\hline
\end{tabular}


Table 2. Covariation between bone histology and the phylogeny assessed as the $\mathrm{R}^{2}$ values of histological variance explained by the tree, as obtained in test of phylogenetic signal using phylogenetic eigenvector regression and regressions on distance matrices. In phylogenetic eigenvector regression, we retained and used the phylogenetic principal coordinate axes significantly related to the dependent variable as explanatory variables. When no axes were retained, the analysis could not be performed. Note that the third phylogenetic signal test (tree length distribution) does not yield an explained variation, so it is not reported here. 


\section{Figure legend}

Figure 1. Phylogeny (topology and divergence dates) including the species of the sample (modified after Cubo et al 2012). The bottom edge contains a time calibration in Ma.

Figure 2. Cross sections in long bone diaphyses of archosaurs in ordinary light. A. Two radial vascular canals (black arrows) in a mostly circular vascular pattern (white arrowheads), in Dromaius novaehollandiae (femur). B. Oblique vascular canals, in Lesothosaurus (femur). C Dense circular vascular pattern, in Struthio camelus (femur). D Osteocytes of Postosuchus (humerus) with fitting ellipses and major (MA) and minor (ma) axes figured to illustrate the measuring process of cell size (the ellipse area) and shape (the ma/MA ratio) in ImageJ. Scale bars : $1 \mathrm{~mm}$ in $1,2,3 ; 0.05 \mathrm{~mm}$ in 4. 
Microcebus murinus





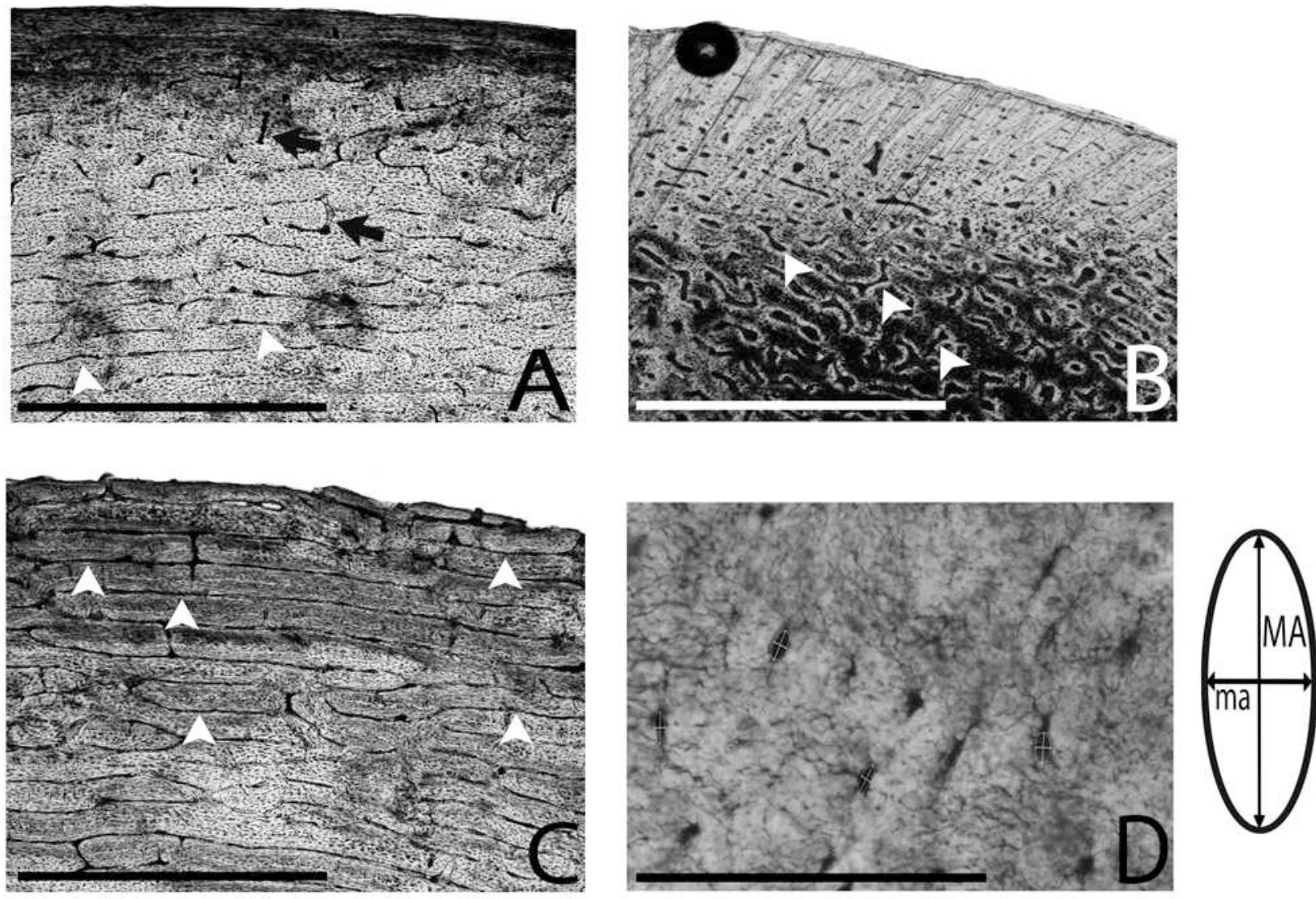